\title{
Evaluating the First, Second and Third Order Barriers of Technology Integration in Primary Education in Nigeria
}

\author{
Rubie Targema-Takema \\ School of Computing, University of Portsmouth, PO1 3HE, Buckingham building, Portsmouth \\ E-mail: rubie.targema-takema@port.ac.uk
}

\begin{abstract}
The use of technology in education has rapidly grown over time, some countries have evolved faster than others for obvious reasons like the rate of development and innovation in countries. Integrating technology in education has become a budding issue worth exploring because of the advantages of technology in education. Barriers in technology integration has left educators integrating technology by diffusion theory, without any sustainable means. The investigation of these barriers in technology integration puts educational institutions in a better place to establish steps to mitigate and possibly eliminate factors that hinder the effective integration of technology in education.This paper explores the first, second and third order barriers of technology integration in primary education in the context of Nigeria. The first order barriers being the factors extrinsic to educators, the second order, being the factors intrinsic to the educators and the new third order, being a creative ability of the educator to merge both extrinsic and intrinsic factors to implement technology in education.This paper evaluates each order in the Nigerian environment and proposes solutions that could improve the integration of technology in Education. Keywords: Education technology, Technology integration, Education, Technology
\end{abstract}

DOI: $10.7176 / \mathrm{JEP} / 12-30-05$

Publication date:October $31^{\text {st }} 2021$

\section{Educational Technology}

Technology has proven to be a useful tool in the Education sector. We have seen countries all around the world deploy digital means to facilitate teaching and learning. This shift did not just happen overnight. It was believed that the way Learners were educated needed to change because it appeared there were several factors calling for this change (Bach, 2012; Kaku, 2012). Facer \& Sandford (2010) put it as a call for a redesign of the 21 st century Education all around the world. The reason for the redesign of the system is said to have become clearer through the years in various research that highlighted technology as the biggest driver in this redesign as seen in Bach (2012) and Facer \& Sandford (2010) who agree that "Technology, while not a silver bullet, will allow Education to expand beyond the formal classroom and into the society that Learners interact with every day".

The Educational Technology field has thus rapidly expanded because research has shown that technology will play a huge role in human life at large but, particularly in Education. Some examples include the use of iPad and tablets for Online learning, the use of Learning Management Systems for distanced learning and the use of Virtual reality (VR) and Augmented reality (AR) to help students understand how theoretical problems may be solved in real-world examples. Both technologies allowing one to see virtual content layered on top of a real-time video feed of the real world by using VR/AR-enabled devices (Mercieca, 2016).

Omar et al. (2012) explained that the mode of learning among Students in the digital age is quite different compared with the past generations of Students. The digital age learners are active experiential learners, proficient in multitasking and dependent on communication technologies to access information and to interact with others. The researcher observes that this trend is made possible by the unprecedented growth of Information and Communication Technologies such as mobile computers, phones, social networks, online games, live-streams, and Internet wireless connections which have resulted in ease of access of a bulk of knowledge and enhanced digital communication across the world. Leer \& Ivanov (2013) highlight similar advantages of Technology in Education, but with a caveat, stating that "Technology can be an incredibly powerful tool in assisting students to learn in a way that suits them best, but Administrators must be careful not to give greater priority to having Technology than to using it effectively". So, while it is important to advance with the world in the introduction of Technology to the learning space, the driving force behind this introduction must be to facilitate the teaching and learning process. Christensen, Johnson \& Horn (2012) agree that the addition of Technology to traditional education models does not automatically reform or advance the Education field by helping students achieve their educational goals successfully, rather, is only as good as the humans that develop and use it. These reveal that Technology can be said to be a means to an end but not necessarily the end, Educational Institutions have to move from introducing Technology to Education to introducing Technology that best aids the achievement of learning outcomes for both the Educators and Students.

Tijani (2009) submits that the usage of Technology for instructional purposes enhances students' learning more in less time, without time and space constraints and no observable reduction in the quality of instruction being received. By further implication, technology serves as the platform that equips students to organise their 
learning process.

\section{Educational Technology in Primary Education in Nigeria}

As of 2018, there was an estimated 63 thousand Primary schools in Nigeria with the highest number registered in the North-west and the lowest in South-east (Statista, 2018).

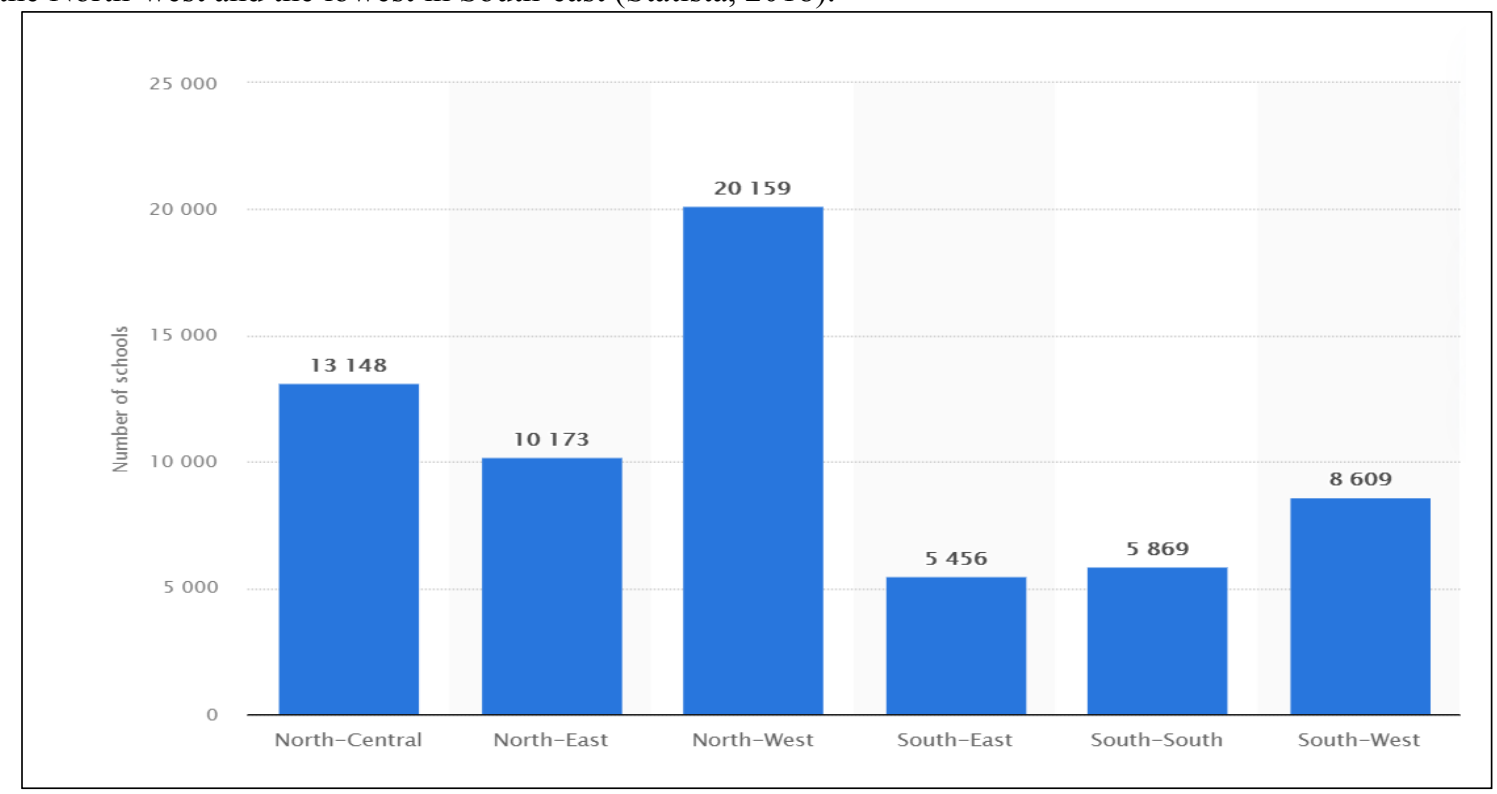

Figure 1. Number of public elementary schools in Nigeria as of 2018, by zone (Statista, 2018)

The Educational System in Nigeria is witnessing an optimistic transformation in this age of knowledge explosion. In the findings of Agbetuyi and Oluwatayo (2012), one interesting thing about ICT in the Nigeria Educational system is that it has served as a transformational tool that has promoted the shift to a Learner-centred environment Awotokun, (2016), Bach (2012). Before now, the education system in Nigeria has largely been traditional and manual, students being limited to the knowledge of the teacher and having access to resources only through books given in school which also proved limiting.

Educational technology has helped to increase access to learning resources, improving policy formulation and widening the range of opportunities for Education for every social class. The internet and World Wide Web also came with a wealth of learning materials in almost every subject and in a variety of media forms which is accessible from anywhere at any time of the day by an unlimited number of people thereby creating limitless possibilities with learning.

Taiwo \& Adewuni (2013), Soetan \& Coker (2018) highlight more benefits of Educational Technology in Nigeria stating that most Tertiary institutions now adopt e-application, e-admission and e-registration for its Students; it has equally become a field of study in Colleges of Education, Polytechnics and Universities. Both the Science and Technology of the course have become areas of specialisation to many students at undergraduate, graduate and postgraduate levels. The Internet has been instrumental to the increase in access to Education in the Nigerian Educational Technology scene.

While Taiwo \& Adewuni (2013), Soetan \& Coker (2018) have focused on the benefits in tertiary institutions, other studies have attributed its importance from early Primary education to have a higher positive impact (Mogwe \& Balotlegi, 2020).

\section{Educational Technology Integration in Nigeria}

With all the noted advantages of Educational Technology, we meet a hurdle that must be cross to enjoy the benefits of integrated Educational Technology. (Virvou, Katsionis \& Manos, 2005) propose that the recent technology explosion has made learning more complex for many students, therefore Educators should be striving to make learning environments more conducive to learning as even more technologies continue to be infused into the teaching-learning environment. It has become necessary for such technologies to ascertain their usability. The use of Technology in Education is one considered multidimensional. It is necessary to assess technology integration as a dynamic process which includes factors that interact over time rather than simply reducing Technology integration to a question of accessibility Atman \& Usluel (2019). A case study research to identify the barriers of ICT adoption in Botswana Primary education by Mogwe \& Balotlegi (2020) revealed that Technology adoption and its integration have been verbally accepted but its implementation has been a problem. Similar to Nigeria, policies are in place (UNESCO, 2019) but their implementation to integrate technology has been the challenge. 
The research highlighted the technophobia from teachers and students, organisational set up and individual skills on ICT as factors that affect the whole integration process (Mogwe, Keolopile \& Seelo, 2018). As discussed from other studies (Leteane et al, 2015) absence of trained individuals to deliver ICT subjects, lack of ICT support technicians in school environments, lack of ICT resources and the slow approach to acceptance of ICT play an adverse role in the adoption and integration process, and if these factors influencing teachers' adoption of ICT in education system (Buabeng-Andoh, 2012; Kipsoi, Chang'ach \& Sang, 2012) are followed then the change process could be well realized.

Ajayi and Ekundayo (2009) highlight other factors such as conservatism, poor Internet infrastructure, manpower and support (Agbetuyi \& Oluwatayo, 2012; Kwache, 2007), epileptic power supply (Agbetuyi \& Oluwatayo, 2012; Yusuf, 2005) and high cost of Internet facilities as prominent among factors hindering Educator's readiness to use technology for instructional purposes in Nigeria (Agbetuyi \& Oluwatayo, 2012). Will removing these first and second order barriers according to Ertmer, 1999, automatically cause Technology adoption and integration to happen?

\section{Barriers and enablers of Technology in Primary Education in Nigeria}

According to the Baller, et al., (2016), based on the Networked Readiness Index (NRI), the overall conditions for Technology's impacts in Nigeria seem to have deteriorated: both economic and social impacts record a decline as Nigeria ranked 119 on the table. The low ranking is an indication that Nigeria has not been able to leverage Technology for increased competitiveness as well as driving innovations in the country, let alone in the Education sector.

While Ertmer, 1999 classified barriers in Technology integration into two; First order barriers (Extrinsic barriers to the teacher) and Second order barriers (Intrinsic barriers to the teachers), Tsai \& Chai (2012) add a further classification called Third order barriers, arguing that due to the dynamic nature of the classroom, a teacher's ability to creatively design learning materials and adapt the instructional needs of the learner for different contexts is equally as important as their access to sufficient facilities, resources (First order barriers), and their own positive attitudes and beliefs towards Technology (Second order barriers).

\begin{tabular}{|l|l|l|}
\hline $\begin{array}{c}\text { FIRST ORDER BARRIERS } \\
\text { (Extrinsic to Teachers) } \\
\text { (Ertmer,1999) }\end{array}$ & $\begin{array}{c}\text { SECOND ORDER BARRIERS } \\
\text { (Intrinsic to Teachers) } \\
\text { (Ertmer, 1999) }\end{array}$ & $\begin{array}{c}\text { THIRD ORDER BARRIERS } \\
\text { (Design thinking) } \\
\text { (Tsai \& Chai, 2012) }\end{array}$ \\
\hline $\begin{array}{l}\text { Absence of Technology } \\
\text { Insufficient time to plan } \\
\text { Integration }\end{array}$ & $\begin{array}{l}\text { Beliefs about teaching } \\
\text { Technology }\end{array}$ & $\begin{array}{c}\text { Using Technology at the right time } \\
\text { and right place }\end{array}$ \\
\hline Lack of training & Beliefs about classroom practices & Adaptability to environment \\
\hline Inadequate Technical support & Unwillingness to embrace change & Creative ability \\
\hline
\end{tabular}

Table 1. First, second and third order barriers

\section{First Order Barriers}

These can be said to be the easiest barriers to tackle because they are all external factors that are independent of the Teacher or Learner. Further examination of these barriers has shown the responsibility to be more on the Government first, and then the Leaders of the Educational institutions.

\section{Absence of Technology}

Studies have shown that Nigeria has expressed commitment to education, which has accounted for various policy initiative such as National Policy on Education (NPE) by the government, as education is considered as an instrument necessary for effective national development (Bolaji, Grey, Campbell-Evans, 2015), yet there has been little evidence of the impact of these bodies put in place.

There is a high presence of mobile technology in the country, with an estimated 15-20 million smartphones registered to various mobile network operators as of 2014 and 93.5 million active mobile internet connections in 2016 (Adegboye, 2016; Oyelere, et al., 2018).

This could be leveraged on to improve the conditions necessary for quality Educational technology use in Nigeria because it appears the Technology is present (UNESCO, 2018).

Several studies (Agbetuyi \& Oluwatayo, 2012; Tella, Tella, Toyobo, Adika \& Adeyinka, 2007) also revealed epileptic power supply as barriers to technology integration. Access to electricity is explained to have impact on education through lighting that can be used for reading, leisure, and entertainment while providing access to information that leads to non-formal education (Olanrele et al, 2019).

The electricity needs of developing country was estimated at about 1,000MW per million people (www.financialnigeria. com, 13 Jan 2016), by implication, Nigeria will require about 200,000MW electricity generation for its population of over 200 million (Lawal, Olayanju, Ayeni, \& Olaniru, 2019). Foreshadowing the 
results of Olanrele et al (2019), it can be deduced that children educational outcome increases with the educational level of the household head by $21 \%$ and their study time reduces with household access to electricity by $8 \%$. Even if all the necessary learning technologies were made available for students both in school and outside of school, with the current level of electricity supply in Nigeria, a lot of Educators and Learners will still struggle to integrate technology as electric power will be absent to charge or power up devices as at when needed.

In the Nigerian setting, the barrier might not be an absence of technology, but an absence of the factors to sustain these technologies in achieving its purpose in Education.

\section{Insufficient time to plan Integration}

Tabowei (2021) in researching into the Potentials of Mobile Technologies in Nigerian College of Education highlighted a need for a review of the Nigerian curriculum in Education across all levels to incorporate the time needed to teach with technology and the measures to foster teacher development and training. His study reveals the concerns of absence of sufficient time for Educators to factor in learning to use a Technology before even integrating it to their teaching. According to Lim \& Khine (2006), the classroom environment is a complex and dynamic one that places a high level of demand on the Educator, especially when he/she attempts to integrate innovative tools or practices into his/her classroom instructions. Some of this pressure could be alleviated or better controlled if Educators have more time given in the curriculum to learn the needed learning technology and have the time required to integrate it to the learning environment without fear of falling short in meeting learning outcomes as at when due, bearing in mind that they cannot rush through teaching if students are not understanding it a learning technology's application or use.

\section{Lack of Training}

Garba (2014) notes that most of the educational practitioners in Nigeria at all levels of learning lack the necessary skills needed for the use of technology in their practices. This skill and competence barrier were also highlighted by Dele-Ajayi (2018) from their work with Evaluating Digital Educational games for Teaching Mathematics in Nigeria. Teachers in this study were concerned about the lack of training required to work with digital technologies in the classroom. As inferred from some of the concerns they shared, the main challenge is that the confidence needed to use technology is absent and hence would be hard to use it in the classroom before being trained to do so. The low level of digital literacy among Nigerian teachers can be attributed to the fact that teacher training institutions in Nigeria are yet to fully integrate Technology in their Teacher education programs. Colleges of Education award the Nigerian Certificate of Education (NCE), which is the minimum qualification to be an Educator in Nigeria, however, the training programme is mostly theory-driven and usually leaves teachers unprepared for a practical and engaged classroom (De et al, 2016).

\section{Inadequate Technical support}

Strongly tied to the previous barrier of a lack of training for Nigerian Educators with Technology is the absence of technical support to Educators who even take the plunge in spite of their digital illiteracy and agree to integrate technology in their teaching.

Teachers that do not feel supported by the school leadership in providing technical persons for support also pose a threat to their decision to integrate technology to their teaching.

\section{Second Order Barriers}

The idea teachers have about digital technologies, as well as their pedagogy beliefs have been proven to have a direct impact on how teachers adopt and integrate technology in their classrooms (Leem \& Sung, 2018; Koh et al, 2015). According to Kim et al (2013), their belief are regarding concerns about the value of technology for students' learning and self-efficacy along with other beliefs concerning teaching and learning with technology. A case study by Dele-Ajayi et al (2019) in investigating solutions to integrating technologies in the classroom had a quote from a Teacher in a Nigerian primary school; "Some of us think it is a waste of time as there are more important things to do in the classroom than play with computers". This teacher's response suggests that they consider using computers and other digital devices as a waste of time and an unnecessary distraction that should not be allowed in the classroom. Rather than see it as aid, they see it as distraction.

Beliefs as such about teaching and about computers very easily hamper on a teacher's decision to integrate technology. We cannot expect the quoted teacher to jump at the idea of integrating technology to teach even if technology was readily available.

Another teacher in same study was quoted saying "If I take the students into the ICT lab, I am responsible for that period, and with the principal constantly reminding us to be careful around the computers, you just feel it is not worth the stress". This teacher revealed fear to handle the technology made available to teach students because he/she bears the brunt for whatever goes wrong with the devices. Again, such a teacher is less likely to engage technology to teach knowing that they will be held responsible in an event that a student mishandles or spoils the 
available technology. Maybe if teachers were allowed to focus on the task of teaching and not be burdened with fear of what happens to available technology in school, they might be more likely to integrate available technology in teaching.

Teachers' beliefs can be changed by their level of self-efficacy with these learning technologies. If they feel empowered with the knowledge and further technical support as highlighted in first order barriers, they might accept the idea of integrating technology even more.

\section{Third Order Barriers}

If a teacher has all first and second order barriers eliminated, while it might heavily impact their willingness to integrate technology, he/she may still not have a successful implementation Tsai \& Chai (2012). The Third order barrier Researchers propose that the need for design thinking skills and disposition may be the last piece needed for technology integration as classroom contexts and learners are quite dynamic, the teacher would require some design thinking to create learning materials and activities, adapting to the instructional needs for different contexts or varying groups of learners.

The researchers introducing the third order barrier describe design thinking as the ability of a teacher to creatively use what they have to achieve what they can in the learning outcomes. Things like designing quizzes or activities around the available learning technologies and topics could facilitate the integration process.

Tsai and Chai (2012) submit that the cultivation of design thinking should be an ongoing effort and not a one off, regardless of the level of technology made available in the environment. Pavlou (2019) in a case study exploring digital storytelling as a transformative pedagogy in primary education shares similar thoughts, stating that critical design thinking is important for studying important real-life issues with children and bridging the gap between school life and daily life.

Idiosyncratic barriers will always exist in one form or another but attending to the issues raised across the first, second and third order barriers in the Nigerian Education scene will arguably eliminate most of the difficulties for integration of Technology in Education.

In the near future, as more technology is infused in the learning environment, teacher trainings must grow to accommodate a curriculum that addresses each order of the barriers to eliminate factors that might hinder effective technology integration. Learning technologies should be exposed to educators first in training before to students in the classroom for teaching.

\section{References}

Adegboye, Y. (2016) Mobile Technology in Nigeria: Statistics, History, Setting. Retrieved from: http://mobilityarena.com/quick-facts-mobile-nigeria

Agbetuyi, and J.A. Oluwatayo, Information and Communications Technology (ICT) in Nigeria educational system Mediterranean. Journal of Social Sciences, Vol. 3, No. 3, 2012

Ajayi, I., Ekundayo, T. (2009). The application of information and communication technology in Nigerian secondary $\quad$ schools. Retrieved from https://academicjournals.org/article/article1381231790_Ajayi\%2520and\%2520Ekundayo.pdf

Atman, N., Usluel, Y. (2019). Predicting Technology Integration based on a conceptual framework for ICT use in education. Retrieved from https://www.tandfonline.com/doi/pdf/10.1080/1475939X.2019.1668293

Awotokun, O. (2016). Information and Communications Technology (ICT) in Nigeria Educational Assessment System - Emerging Challenges. Universal Journal of Educational Research 4(6): 1351-1356

Bach, D. (2012). We need to rethink...everything. Retrieved from https://bized.aacsb.edu/articles/2012/09/weneed-to-rethink-everything

Baller, S., Dutta, S., Lanvin, B., 2016. The Global Information Technology Report 2016. Innovating in the Digital Economy. World Economic Forum and INSEAD, Geneva

Bolaji, S., Gray, J.,Campbell-Evans, G. (2015). Why Do Policies Fail in Nigeria? Journal od education, society and behavioural science, 2(5)

Buabeng-Andoh, C. (2012). An Exploration of Teachers' Skills, Perceptions and Practices of ICT in Teaching and Learning in the Ghanaian Second-Cycle Schools. Contemporary Educational Technology, 3(1). Retrieved from Http://Search.Ebscohost.Com

Christensen, M., Johnson, W., Horn, B. (2012). "Disrupting Class: How Disruptive Innovation Will Change the Way the World Learns.”. 2nd edition. ISBN: 978- 0071749107

De, S., Pettersson, G., Morris, R., Cameron, S. (2016). "Teacher Development Programme (TDP)"

Dele-Ajayi, O. (2018). "How Can Digital Educational Games be Used to Engage Pupils with Mathematics in the Classroom". PhD Thesis

Ertmer, P. A. (1999). Addressing first- and second-order barriers to change: Strategies for technology integration. Educational Technology Research and Development, 47(4), 47-61. http://dx.doi.org/10.1007/BF02299597

Facer, K., \& Sandford, R. (2010). The next 25 years: future scenarios and future directions for education and 
technology. Journal of Computer Assisted Learning, 26 (1)

Garba, S. Effective Integration of ICT in Educational Practices; a Review of the Situation in Nigeria. American Journal of Science and Technology. Vol. 1, No. 3, pp. 116-121, 2014.

Kaku, M. (2012). Physics of the future: how science will shape human destiny and our daily lives by the year 2100 (1st ed.). New York: Anchor Books

Kim, C., Kim, M. K., Lee, C., Spector, J. M., \& DeMeester, K. (2013). Teacher beliefs and technology integration. Teaching and Teacher Education, 29, 76-85

Kipsoi, E. J., Chang'ach, J. K., \& Sang, H. C. (2012). Challenges Facing Adoption of Information Communication Technology (ICT) in Educational Management in Schools in Kenya. Journal of Sociological Research, 3(1), Pages-18

Kwache, P. Z. (2007). The imperatives of information and communication technology for teachers in Nigeria Higher Education. Merlot Journal of Online Learning and Teaching, 3(4), 359-399

Lawal, A.I, Olayanju, A., Ayeni, J., Olaniru, O.S. (2019), Impact of bank credit on agricultural productivity: Empirical evidence from Nigeria (1981-2015). International Journal of Civil Engineering and Technology, 10(2), 113-123

Leer, R. \& Ivanov, S., (2014). Applied organizational study of free jobs training program in Washington DC: Research case on structuring of workforce development in the capital of the United States. International Journal of Organizational Innovation, (2014), 33-46, 6(4)

Leteane, O., Kgalemang, C., Moakofhi, M., Pholele, T.M, and Phiri. T. (2015). "Usage, Challenges And Perceptions Of ICT By Teachers In Junior Secondary Schools In Botswana,"BUIRC Conference, Botho University Botswana

Lim, C. P., \& Khine, M. S. (2006). Managing teachers' barriers to ICT integration in Singapore schools.(information and communication technologies). Journal of Technology and Teacher Education, 14(1), 97-125

Mercieca, D. (2016), “An investigation of the use of augmented reality in the presentation of comics". Retrieved from https://www.um.edu.mt/library/oar/handle/123456789/16377

Mogwe, A., Keolopile, B., and Seelo, G. (2018). "The need for e-learning in lower educational levels in Botswana: Developing the smart kid corner application, "NERA: Proceedings of the 17th BOLESWANA Biennial Research Symposium 10-12 July 2018, University of Namibia, Namibia. p.179-184

Mogwe, A., Balotlegi, P. (2020). Barriers of information communication technology (ICT) adoption in Botswanas' primary education. Retrieved from https://files.eric.ed.gov/fulltext/EJ1266572.pdf

Olanrele, I., Isola, L., Olatunde, D., Abiola, B., Joseph I. (2019). The impact of access to electricity on education and health sectors in Nigeria's rural communities. Retrieved from https://www.researchgate.net/publication/342369404

Oyelere, S. S., Suhonen, J., Sutinen, E. and Wajiga, M. G., (2018) Design, development, and evaluation of a mobile learning application for computing education. Education and Information Technologies. 23 (1), pp. 467-495

Pavlou, V. (2019). Art Technology Integration: Digital Storytellying as a Transformative Pedagogy in Primary Education. Retrieved from https://onlinelibrary.wiley.com/doi/10.1111/jade.12254

Soetan, A., \& Coker, A. (2018). University lecturers' readiness and motivation in utilising online technologies for instructional delivery in Kwara State. Retrieved from www.wj-et.eu.

Statista, (2018). Number of public elementary schools in Nigeria as of 2018, by zone. Retrieved from https://www.statista.com/statistics/1130124/public-elementary-schools-in-nigeria-by-zone/

Tabowei, A. (2021). Technology Enhanced Learning: A Case Study of the Potentials of Mobile Technologies in Nigerian College of Education. PhD Thesis

Taiwo, M., Adewuni, S. 92013). Trend analysis of candidates' enrolment in NABTEB Information and Communications Technology: A paper presented during the 2nd Institute of Education international conference, University of Ibadan, Ibadan, Nigeria.

Tella, A., Tella, A., Toyobo, O., Adika, O., Adeyinka, A. (2007). An Assessment of Secondary School Teachers Uses of ICT's: Implications for Further Development of ICT's Use in Nigerian Secondary Schools. Retrieved from https://eric.ed.gov/?id=EJ1102593

Tijani, O. (2009). Impact of ICT presentation modes on students learning outcomes in S.S.C.E. Economics in Oyo state, Nigeria. Teacher Education Department, University of Ibadan, Nigeria

Tsai, C., Chai, C. (2012). The "third"-order barrier for technology-integration instruction: Implications for teacher education. Australasian Journal of Educational Technology 2012, 28 (Special issue, 6), 1057-1060

UNESCO, (2018). Youth mobile, Empowering the next generation. Retrieved from https://en.unesco.org/sites/default/files/youthmobile_report_2018.pdf

Virvou, M., Katsionis, G., \& Manos, K. (2005). Combining Software Games with Education: Evaluation of its Educational Effectiveness. Educational Technology \& Society, 8(2), 54-65 